\title{
STRATEGI INTERNALISASI NILAI-NILAI MORAL RELIGIUS DALAM PROSES PEMBELAJARAN DI PERGURUAN TINGGI
}

\author{
Mukhamad Murdiono \\ FISE Universitas Negeri Yogyakarta (e-mail: mukhamad_murdiono@uny.ac.id; \\ HP. 08156870193)
}

\begin{abstract}
A Strategy to Internalize Moral and Religious Values in Learning Processes in Higher Education. This study aims to describe a strategy to internalize moral and religious values in learning processes in higher education. This research was a descriptive study employing the qualitative approach. The research subjects were lecturers in the Department of Civic and Law Education, Faculty of Social Sciences and Economics, Yogyakarta State University. The data were collected through interviews, observations, and documents. The data trustworthiness was assessed by the triangulation technique. The results show that strategies to internalize moral and religious values in learning processes include: modeling, analyzing actual problems in society, developing contextual educative values, and strengthening moral values that the students have already possessed.
\end{abstract}

Keywords: strategy to internalize moral and religious values, learning processes

\section{PENDAHULUAN}

Pendidikan merupakan pilihan strategis bagi suatu bangsa untuk bangkit dari keterpurukan. Begitu pun bagi Indonesia, sudah menjadi keharusan untuk menempatkan pendidikan sebagai prioritas utama dalam pembangunan. Secara tegas upaya untuk menciptakan sumber daya manusia yang berkualitas tersebut tertuang dalam lembaran yuridis negara berupa Undang-Undang tentang sistem pendidikan nasional. Melalui Undang-Undang Nomor 20 Tahun 2003 tentang Sistem Pendidikan Nasional, pemerintah mengusahakan dan menyelenggarakan satu sistem pendidikan nasional yang dapat meningkatkan keimanan dan ketakwaan kepada Tuhan Yang Maha Esa serta akhlak mulia dalam mencerdaskan kehidupan bangsa.
Pendidikan sudah sejak zaman dahulu bertujuan untuk membentuk manusia yang utuh dan lengkap meliputi berbagai aspek. Pendidikan tidak hanya berorientasi pada aspek akademis semata dalam rangka penguasaan ilmu dan teknologi. Kemajuan teknologi dan ekonomi tidak menjamin hadirnya rasa bahagia di hati manusianya, malah dapat membawa dampak pada hilangnya jati diri dan makna kehidupan. Pendidikan yang dikembangkan seharusnya seimbang antara kecerdasan intelektual, emosional, dan spiritual. Menghadirkan spiritualitas dalam pendidikan akan memberi makna besar terhadap kehidupan bangsa. Keyakinan terhadap keberadaan Tuhan akan menimbulkan komitmen kuat untuk selalu memberikan yang terbaik untuk bangsa (Agustian, 
2008:15). Internalisasi nilai-nilai moral religius dalam proses pembelajaran merupakan bagian penting yang perlu dikembangkan agar ilmu yang diperoleh peserta didik lebih bermakna.

Nilaidanmoral merupakan dua konsep berbeda yang dalam penggunaannya seringkali disandingkan. Bertens (2007:140) menjelaskan pengertian nilai melalui caramemperbandingkannya dengan fakta. Fakta menurutnya adalah sesuatu yang ada atau berlangsung begitu saja. Sementara nilai adalah sesuatu yang berlaku, sesuatu yang memikat atau menghimbau kita. Fakta dapat ditemui dalam konteks deskripsi semua unsurnya dapat dilukiskan satu demi satu dan uraian itu pada prinsipnya dapat diterima oleh semua orang. Nilai berperanan dalam suasana apresiasi atau penilaian dan akibatnya sering akan dinilai secara berbeda oleh orang banyak. Nilai selalu berkaitan dengan penilaian seseorang, sementara fakta menyangkut ciri-ciri objektif saja. Definisi lain tentang nilai dikemukakan oleh Richard Merril (Koyan, 2000:13), menurutnya nilai adalah patokan atau standar pola-pola pilihan yang dapat membimbing seseorang atau kelompok ke arah satisfaction, fulfillment, and meaning. Menurut Sandin (Koyan, 2000:1314), patokan atau kriteria tersebut memberi dasar pertimbangan kritis tentang pengertian religius, estetika, dan kewajiban moral.

Sementara istilah moral menurut Prent (Cholisin, 1989:25) berasal dari bahasa Latin mores dari suku kata mos, yang artinya adat istiadat, kelakuan, tabiat, watak, akhlak. Ouska dan Whellan (Ruminiati, 2007:32) mengartikan moral sebagai prinsip baik-buruk yang ada dan melekat dalam diri seseorang. Namun demikian, walaupun moral itu berada di dalam diri individu tetapi moral berada dalam suatu sistem yang berwujud aturan. Moral dan moralitas merupakan dua konsep yang berbeda. Moral adalah prinsip baik-buruk sedangkan moralitas merupakan kualitas pertimbangan baik-buruk. Dengan demikian, hakikat dan makna moralitas dapat dilihat dari cara individu yang memiliki moral dalam mematuhi maupun menjalankan aturan.

Dalam menginternalisasikan nilainilai moral; Simon, Howe, dan Kirschenbaum (Wahab, 2007:1.23) menawarkan 4 (empat) pendekatan yang dapat digunakan, yaitu pendekatan penanaman moral, pendekatan transmisi nilai bebas, pendekatan teladan, dan pendekatan klarifikasi nilai. Menurut Kirschenbaum (1995:16-17) pendidikan nilai perlu dilakukan dengan menggunakan pendekatan secara komprehensif. Pendekatan secara komprehensif dalam pendidikan nilai maksudnya adalah pendidikan nilai yang menyeluruh atau komprehensif yang dapat ditinjau dari segi metode yang digunakan, pendidik yang berpartisipasi (guru, orang tua), dan konteks berlangsungnya pendidikan nilai (sekolah, keluarga).

MenurutZuchdi(2008:48) dalam menerapkan metode keteladanan guru dan orang tua perlu memiliki keterampilan asertif dan keterampilan menyimak. Kedua keterampilan ini sangat diperlukan untuk menjalin hubungan antarpribadi danantarkelompok. Oleh karena itu, guru dan orang tua harus dapat dijadikan contoh bagi anak-anak.Keterampilan as- 
ertif adalah keterampilan mengemukakan pendapat secara terbuka dengan cara-cara yang tidak melukai perasaan orang lain. Keterampilan menyimak ialahketerampilan mendengarkan dengan penuh pemahaman dan secara kritis. Kedua keterampilan ini harus dikembangkan secara seimbang karena merupakan komponen vital dalam berkomunikasi. Anak yang memiliki kedua keterampilan ini akan menjadi anak yang dapat menghargai pendapat orang lain dan secara asertif dapat menyampaikan gagasannya kepada orang lain.

Selain komprehensif dari segi metode, pendidikan nilai juga harus komprehensif dari segi isi, waktu, pelaku, dan penilaian. Dari segi isi, pendidikan nilai harus meliputi semua permasalahan yang berkaitan dengan pilihan nilainilai yang bersifat peribadi sampai pertanyaan-pertanyaan etika secara umum. Komprehensif dalam hal waktu ialah pendidikan nilai berlangsung di setiap saat sepanjang hidup anak. Komprehensif dari segi pelaku, bahwa pendidikan nilai dapat dilakukan oleh semua orang dewasa, sadar atau tidak, direncanakan atau tidak direncanakan. Kemudian komprehensif dalam penilaian, maksudnya adalah dalam mengukur efektivitas dan kemajuan pendidikan nilai menggunakan evaluasi formatif dan sumatif yang mengukur pengetahuan, sikap, dan keterampilan nilai.

Uraian di atas, menunjukkan bahwa ada banyak metode yang dapat digunakan dalam menginternalisasikan nilai. Pendidikan nilai dapat dilakukan di setiap jenjang pendidikan, termasuk di perguruan tinggi. Untuk menciptakan suasana kampus yang nyaman, tenteram dan penuh religiusitas tentu menjadi tanggungjawab setiap civitas di sebuah perguruan tinggi. Memulai semua itu tentu perlu kajian mendalam dari mana dan bagaimana metode yang tepat untuk digunakan dalam mengimplementasikan nilai-nilai moral religius dalam kehidupan kampus. Mengingat begitu banyaknya nilai-nilai moral religius yang ada, maka kajian penelitian ini dibatasi pada nilai-nilai moral religius berupa nilai ketaqwaan, kejujuran, keihkhlasan, dan tanggungjawab. Kajian mendalam melalui penelitian tentang internalisasi nilai-nilai moral religius dalam kehidupan kampus merupakan langkah strategis yang harus segera dilakukan. Harapannya melaui sebuah penelitian akan ditemukan suatu model atau strategi yang tepat dan sesuai dalam menginternalisasikan nilainilai moral religius dalam proses pembelajaran di perguruan tinggi.

\section{METODE}

Penelitian ini merupakan penelitian deskriptif dengan menggunakan pendekatan kualitatif. Merupakan penelitian deskriptif karena penelitian ini bermaksud untuk membuat gambaran mengenai situasi atau kejadian, yaitu strategi internalisasi nilai-nilai moral religius dalam proses pembelajaran di perguruan tinggi. Hal ini sejalan dengan pendapat Nazir (2005:55), bahwa penelitian deskriptif bertujuan untuk membuat gambaran mengenai situasi atau kejadian sehingga berkehendak mengadakan akumulasi data dasar belaka. Penelitian ini dilakukan di Jurusan Pendidikan Kewarganegaraan dan Hu- 
kum, Fakultas Ilmu Sosial dan Ekonomi,Universitas Negeri Yogyakarta. Subjek penelitian ini adalah lima orang dosen yang mengajar di Jurusan Pendidikan Kewarganegaraan dan Hukum. Subjek tersebut dipilih berdasarkan pertimbangan rumpun keilmuan yang ada di Jurusan Pendidikan Kewarganegaraan dan Hukum meliputi: rumpun hukum, moral, dan politik.

Teknik pengumpulan data yang digunakan dalam penelitian ini adalah wawancara, observasi, dan dokumentasi. Wawancara digunakan untuk menjaring data atau informasi yang berkaitan dengan strategi yang digunakan dalam internalisasi nilai-nilai moral religius. Obeservasi digunakan untuk memperoleh data mengenai pelaksanaan metode yang digunakan dalam menginternalisasikan nilai-nilai moral religius dalam proses pembelajaran. Dokumentasi digunakan untuk memperoleh data mengenai gambarankeberadaanobjek yang diteliti. Selain itu, untuk melengkapi data hasil wawancara dan observasi. Untuk mendapatkan data yang dapat dipertanggungjawabkan secara ilmiah, $\mathrm{m}$ aka dari data-data yang telah terkumpul terlebih dahulu dilakukan pemeriksaan keabsahannya. Dalam penelitian ini teknik pemeriksaan keabsahan data yang digunakan adalah teknik triangulasi, yaitu teknik penyilangan informasi yang diperoleh dari sumber sehingga pada akhirnya hanya data yang absah saja yang digunakan untuk mencapai hasil penelitian (Arikunto, 2006:18). Teknik triangulasi yang digunakan dalam penelitian ini adalah triangulasi metode dan sumber, yaitu dengan cara mengkonfirmasi ulang informasi hasil wawancara dengan dokumentasi dan observasi. Data penelitian yang diperoleh dari sumber yang berbeda melalui wawancara dikonfirmasi ulang dengan data yang diperoleh melalui observasi dan dokumentasi. Data yang digunakan dalam penelitian ini adalah data yang absah setelah melalui proses penyilangan informasi. Teknik analisis data yang digunakan dalam penelitian ini adalah teknik analisis induktif, yaitu analisis yang bertolak dari data dan bermuara pada simpulan-simpulan umum.

\section{HASIL PENELITIAN}

Dalam menginternalisasikan nilainilai moral religius, setiap dosen memiliki cara atau strategi yang berbeda-beda. Perbedaan tersebut disebabkan karena belum jelasnya nilai-nilai moral religius yang hendak ditanamkan dalam proses pembelajaran. Artinya, belum ada common values (nilai-nilai umum yang disepakati bersama) untuk diimplementasikan dalam proses pembelajaran di kelas. Nilai-nilai moral religius yang masih terlalu umum perlu dijabarkan lebih rinci lagi menjadi indikator-indikator, untuk memperjelas nilai apa saja yang hendak ditanamkan dalam proses pembelajaran. Nilai-nilai moral religius yang hendak diimplementasikan yang masih terlalu umum menyebabkan terdapat penafsiran yang berbeda dari masing-masing dosen terhadap nilainilai moral yang hendak diimplementasikan dalam proses pembelajaran.

Perbedaan sudut pandang terhadap nilai-nilai moral religius berimplikasi terhadap beraneka ragamnya strategi yang diterapkan oleh dosen dalam mengimplementasikan nilai-nilai moral 
tersebut dalam proses pembelajaran. Secara umum ada beberapa strategi yang diterapkan oleh para dosen di Jurusan Pendidikan Kewarganegaraan dan Hukum dalam mengimplementasikan nilai-nilai moral religius dalam proses pembelajaran. Masing-masing strategi yang diterapkan tersebut memiliki ciri dan keunggulan tersendiri. Uraian lengkap dari masing-masing strategi yang diterapkan itu adalah sebagai berikut.

\section{STRATEGI K E T E L A D A N A N (MODELLING)}

Berdasarkan hasil wawancara yang peneliti lakukan, ada beberapa dosen yang menerapkan strategi implementasi nilai-nilai moral religius melalui metode keteladanan. Strategi keteladanan ini dapat dibedakan menjadi keteladanan internal (internal modelling) dan keteladanan eksternal (external modelling). Keteladanan internal dapat dilakukan melalui pemberian contoh yang dilakukan oleh dosen sendiri dalam proses pembelajaran. Sementara keteladanan eksternal dilakukan dengan pemberian contoh-contoh yang baik dari para tokoh yang dapat diteladani, baik tokoh lokal maupun tokoh internasional.

Nilai moral religius berupa ketaqwaan, kejujuran, keikhlasan, dan tanggungjawab dapat ditanamkan kepada mahasiswa melalui keteladanan, baik keteladanan internal maupun eksternal. Keteladanan internal yang dilakukan oleh dosen, misalnya dilakukan dengan cara mengawali dan mengakhiri setiap perkuliahan dengan berdoa. Dosen senantiasa memberi contoh untuk disiplin dalam beberapa hal seperti kebersihan ruang kelas, datang tepat waktu, dan memiliki komitmen terhadap kontrak belajar yang telah disepakati bersama. Untuk dapat menjadi teladan yang baik diperlukan suatu proses yang panjang. Seorang dosen melalui kebiasaan-kebiasaan baik yang selalu dia lakukan didalam kelas dapat diteladani oleh mahasiswa.

Hal lain yang dapat dilakukan dosen terkait dengan keteladanan internal adalah melalui pemberian atau cerita tentang "pengalaman religius" yang dialami oleh dosen. Terkadang ada seorang dosen yang memiliki pengalaman religius menarik dalam hidupnya, dan hal itu menjadi sesuatu menarik yang dapat diteladani oleh mahasiswa. Sebagai contoh mengenai kekuatan sebuah doa yang mengalahkan segala-galanya. Kedekatan kepada Allah sebagai Tuhan yang Maha Pengasih dan Penyayang telah mengantarkan kepada suatu kesuksesan yang mungkin tidak disangka sebelumnya. Pengalaman semacam inimenunjukkan pentingnya pemahaman tentang keberadaan sesuatu Yang Maha Kuasa di atas segala-galnya. Artinya, pemahaman tentang nilai-nilai religius terutama terkait dengan nilai ketaqwaan dalam kehidupan seorang manusia menjadi suatu hal yang penting.

Keteladanan yang kedua adalah keteladanan eksternal, yaitu keteladanan yang datang dari luar diri dosen. Keteladanan semacam ini dapat dilakukan misalnya dengan menyajikan cerita tentang tokoh-tokoh agama yang dapat dijadikan sebagai teladan dalam meniti kehidupan. Sebagai contoh, tokoh Nabi Muhammad, para sahabat nabi, Jenderal Besar Soedirman, dan tokoh-tokoh 
penting lain baik di Indonesia maupun di luar Indonesia yang patut untuk diteladani. Penyajian cerita yang menarik tentang kisah para tokoh tersebut diharapkan menjadikan mahasiswa mengidolakan dan meniru tindakan positif yang mereka lakukan. Para tokoh tersebut memiliki sikap ketaqwaan, kejujuran, keikhlasan, dan tanggungjawab yang dapat diteladani oleh para mahasiswa. Nabi Muhammad merupakan contoh atau teladan sosok manusia yang memiliki ketaqwaan luar biasa yang patut untuk diteladani.

Selain melalui kisah para tokoh teladan,strategi keteladanan eksternal dapat dilakukan dengan memutarkan film-film tokoh. Misalnya keteladanan tentang kegigihan seorang penulis melalui film freedom writers. Atau kisah-kisah terbaru seperti film "Laskar Pelangi". Dari kisah-kisah yang disajikan melalui film tersebut mahasiswa dapat memetik suatu hikmah yang bermanfaat untuk dirinya. Kejujuran, keikhlasan, tanggungjawab, kepolosan, kegigihan, kerja keras, dan masih banyak lagi nilai-nilai moral yang dapat diteladani melalui cerita film yang ditayangkan di dalam kelas. Mahasiswa dapat menganalisis dan mendiskusikan cerita film yang ditayangkan di dalam kelas, sehingga suasana pembelajaranpun akan menjadi lebih menarik.

Melalui strategi keteladanan ini, memang dosen tidak secara langsung memasukan hal-hal terkait dengan keteladanan itu dalam rencana pembelajaran. Artinya, nilai-nilai moral religius seperti ketaqwaan, kejujuran, keikhlasan, dan tanggungjawab yang ditanamkan kepada para mahasiswa merupa- kan sesuatu yang sifatnya hidden curriculum. Melalui cerita para tokoh penting dan pemutaran film seorang dosen berharap nilai-nilai yang terkandung di dalamnya dapat menjadi sesuatu yang menarik dan dapat ditiru atau diteladani oleh para mahasiswa.

\section{ANALISIS MASALAH ATAU KASUS}

Ada dosen di Jurusan PKn dan $\mathrm{Hu}-$ kum yang menerapkan strategi ini dalam mengimplementasikan nilai-nilai moral religius dalam proses pembelajaran. Mahasiswa diberikan tugas untuk menganalisis kasus yang memuat nilainilai moral religius. Kasus-kasus tersebut mereka dapatkan melalui penelusuran artikel di berbagai media. Nilai moral religius yang hendak ditanamkan melalui strategi ini adalah nilai moral ketaqwaan, kejujuran, keikhlasan, dan tanggungjawab. Setelah mereka menemukan sejumlah kasus yang mengandung nilai-nilai moral religius tersebut, langkah selanjutnya adalah melakukan analisis kasus.

Strategi ini sebenarnya dapat dikatakan sebagai bentuk dari klarifikasi nilai (value clarification). Karena dalam pelaksanaannya mahasiswa diminta untuk melakukan klarifikasi terhadap nilai-nilai yang terkandung dalam suatu masalah yang mereka temukan. Dari analisis kasus itulah mahasiswa akan mendapatkan nilai positif dan negatif dari sebuah kasus. Dengan kata lain strategi ini hampir sama dengan problem based learning. Mahasiswa diminta untuk menganalisis permasalahan, lalu mereka memberikan solusi terbaik terhadap permasalahan yang mereka diskusikan. Setelah permasalahan selesai 
mahasiswa dapat mengambil hikmah atau dapat belajar dari masalah yang dia pecahkan tersebut.

Strategi analisis masalah atau kasus ini sebenarnya menjadi sesuatu yang menarik dan penting untuk dilakukan. Permasalahan-permasalahan tentang implementasi nilai-nilai religius seperti ketaqwaan, kejujuran, keikhlasan, dan tanggungjawab dalam kehidupan sehari-hari sering ditemukan dalam tulisantulisan atau artikel di media massa. Apalagi artikel-artikel yang dimuat di media massa ini biasanya merupakan artikel yang sedang aktual untuk dibicarakan. Misalnya, terkait dengan nilai moral kejujuran dan tanggungjawab. Seringkali media massa memuat artikel tentang kasus korupsi dan penyalahgunaan kekuasaan oleh pejabat pemerintah. Artikel-artikel yang memuat berbagai kasus tersebut dapat dijadikan sebagai sarana bagi mahasiswa untuk menganalisis muatan nilai moral yang terkandung di dalamnya. Melalui pembahasan yang menarik di kelas mahasiswa biasanya akan merasa senang dan serius dalam mengikuti perkuliahan.

Hal terpenting lain yang perlu diperhatikan dalam menerapkan strategi analisis kasus ini adalah bagaimana mahasiswa dapat menerapkan nilainilai moral religius tersebut dalam kehidupan nyata. Mahasiswa tidak saja mampu melakukan analisis kasus dan dapat memecahkannya, melainkan dapat secara nyata meningternalisasikan nilai-nilai moral religius tersebut dalam kehidupannya. Jadi, setelah membahas atau menganalisis kasus yang ada dalam artikel, mahasiswa dapat menemukan nilai-nilai religius seperti ketaqwa- an, kejujuran, keikhlasan, dan tanggungjawab. Nilai-nilai tersebut harapannya dapat diimplementasikan dalam kehidupan sehari-hari. Sehingga secara perlahan tapi pasti kepribadian atau moral mahasiswa akan terbentuk menjadi kepribadian yang baik.

\section{PENANAMAN NILAI EDUKATIF YANG KONTEKSTUAL}

Strategi ini dapat dilakukan dengan secaralangsung atautidak langsung memasukan nilai-nilai moral religius dalam materi pembelajaran. Konsep-konsep yang dikembangkan dalam suatu mata kuliah harus mengandung nilainilai edukatif. Artinya, konsep yang dikembangkan dalam suatu mata kuliah jangan hanya mengedepankan kajian teoritis tentang pengembangan ilmu tersebut. Akan tetapi bagaimana konsepkonsep yang dikembangkan juga mengandung unsur-unsur edukatif penting yang patut untuk dipelajari.

Dalam memberikan konsep-konsep yang memiliki nilai edukatif ini sebaiknya dimulai dari hal-hal yang sifanya kontekstual dan aktual. Misalnya saja terkait dengan pengesahan rancangan undang-undang anti pornografi dan pornoaksi. Pro dan kontra rancangan undang-undang ini menjadi sesuatu yang menarik untuk diberikan di kelas. Dosen dalam memberikan contoh-contoh yang kontekstual dan aktual ini dapat dilakukan ketika melakukan kegiatan apersepsi atau pendahuluan pembelajaran.

Untuk dapat secara jelas menanamkan nilai-nilai edukatif yang kontekstual, maka perlu dimasukan ke dalam proses pembuatan perancangan pembe- 
lajaran di kelas. Dosen dapat membuat dan menuliskan nilai-nilai edukatif yang mengandung unsur religius yang meliputi nilai ketawqaan, kejujuran, keikhlasan, dan tanggungjawab dalam rencana pelaksanaan pembelajaran. Artinya, nilai-nilai moral religius tersebut dituliskan secara jelas kapan akan disampaikan dan memerlukan waktu berapa lama dalam penyampaian nilainilai moral religius tersebut di kelas.

Permasalahannya terletak pada belum adanya nilai-nilai moral religius kontekstual permanen yang telah disepakati bersama. Nilai-nilai moral religiusyang aktual dan kontekstual seringkali berjalan seiring dengan permasalahan yang sedang muncul di masyarakat.Misalnya, ketika sedang membicarakan kasus korupsi akan menjadi tema yang aktual dan kontekstual untuk menanamkan nilai moral berupa kejujuran dan tanggungjawab. Akan tetapi ketika kasus korupsi sudah tidak aktual lagi, maka nilai moral religius yang kontekstual akan berganti. Oleh karena itu, perlu dilakukan suatu lokakarya untuk menentukan nilai-nilai moral religius yang kontekstual. Melalui kegiatan seperti lokakarya diharapkan akan disepakati nilai-nilai apa saja yang sifatnya kontekstual dan dapat diterapkan dalam proses pembelajaran di kelas.

\section{PENGUATAN NILAI-NILAI YANG ADA}

Strategi ini dilakukan dengan sebuah asumsi bahwa mahasiswa sebenarnya telah memiliki nilai-nilai moral religius seprti ketaqwaan, kejujuran, keikhlasan, dan tanggungjawab. Namun bagaimana keyakinan dan pengamalan merekaterhadap nilai-nilai tersebut perlu untuk dikuatkan. Keyakinan terhadap nilai-nilai moral religius yang telah dimilikiolehmahasiwa terkadang mengalami pasang surut. Mahasiswa terkadang karena pengaruh lingkungan atau teman sebaya melupakan akan pentingnya nilai-nilai moral religius tersebut dalam kehidupan sehari-hari.

Setiap dosen sebenarnya memiliki kesempatan yang sama untuk dapat melakukan hal itu. Dosen dapat menyisipkan ruh nilai-nilai moral religius dalam setiap perkuliahan. Penguatan dapat dilakukan dosen setiap saat memberikan kuliah. Artinya, tidak perlu secara langsung menuliskannya dalam sebuah rencana pelaksanaan pembelajaran di kelas. Penyisipan nilai-nilai moral religius ini juga dapat dilakukan untuk setiap mata kuliah. Setiap dosen pengampu mata kuliah dapat melakukan penguatan nilai-nilai moral religius. Hanya saja bagaimana bentuk penguatan nilai-nilai moral yang dilakukan masing-masing dosen memiliki kekhasan. Penguatan nilai-nilai moral religius seperti ketaqwaan, kejujuran, keikhlasan, dan tanggungjawab bukan semata-mata menjadi tanggung jawab dosen yang mengampu mata kuliah Pendidikan Agama.

Keberanian untuk setiap saat menyisipkan ruh nilai-nilai moral religius dalam perkuliahan menjadi tantangan besar para dosen. Semua itu dilakukan melalui suatu proses yang panjang. Tidak serta merta nilai-nilai moral religius ini akan menjadi nilai-nilai yang langsung terinternalisasi dalam diri mahasiswa. Proses panjang itu tetap harus dilakukan agar para mahasiswa memi- 
liki pemahaman yang kuat terhadap nilai-nilai moral religius yang harus mereka implementasikan dalam kehidupan sehari-hari. Selain itu, perlu ada komitmen dan kerjasama antar dosen pengampu mata kuliah untuk menciptakan sistem atau suasana pembelajaran yang memungkinkan nilai-nilai moral religius tersebut dapat ditanamkan dengan baik.

\section{PEMBAHASAN}

Strategi internaliasi nilai-nilai moral religius dalam proses pembelajaran yang diterapkan oleh masing-masing dosen memiliki keragaman. Strategi tersebut dipilih berdasarkan nilai moral religius apa yang akan ditanamkan kepada mahasiswa. Setiap nilai moral memiliki karakteristik tersendiri sehingga tidak dapat menggunakan metode yang sama untuk semua nilai moral religius yang akan ditanamkan kepada mahasiswa. Keberhasilan metode internalisasi nilai-nilai moral religius yang digunakan juga sangat tergantung kepada kemampuan dan pengalaman seorang dosen dalam memilih dan menerapkan metode yang tepat untuk menginternalisasikan nilai-nilai moral yang akan ditanamkan.

Sebelum menerapkan metode internalisasi nilai-nilai moral religius dalam proses pembelajaran, seharusnya ada kesepakatan bersama mengenai nilai moral religius apa yang akan diinternalisasikan dalam proses pembelajaran. Kemudian setelah disepakati, nilai-nilai tersebut perlu dijabarkan ke dalam indikator-indikator yang lebih terperinci. Adanya pemahaman yang sama terhadap nilai moral religius yang akan di- tanamkan kepada mahasiswa sebenarnya dapat memudahkan para dosen ketika akan memilih strategi yang tepat untuk menginternalisasikan nilai-nilai moral religius dalam proses pembelajaran. Perbedaan pemahaman atau persepsi mengenai nilai-nilai moral religius yang akan ditanamkan menyebabkan beragam pula metode yang pilih oleh para dosen.

Strategi internalisasi nilai-nilai moral religius dalam proses pembelajaran dapat diterapkan oleh dosen secara terencana ataupun tidak terencana. Secara terencana dilakukan melalui memasukkan indikator-indikator nilai moral religius yang akan ditanamkan ke dalam rencana pelaksanaan pembelajaran. Dosen membuat skenario pembelajaran yang sengaja dirancang untuk menanamkan nilai-nilai moral tertentu dalam pembelajaran. Dosen dapat pula menyisipkan nilai-nilai moral religius ketika menyampaikan materi perkuliahan. Secara tidak terencana, dosen dapat memasukkan nilai-nilai moral pada saatsaat tertentu yang memungkinkan seorang dosen dapat menyisipkan nilainilai moral religius. Penyisipan nilainilai moral religus ini dapat dilakukan di bagian pendahuluan, inti, ataupun penutup perkuliahan.

Berdasarkan uraian hasil penelitian yang telah dikemukakan, menunjukkan bahwa pendekatan yang digunakan oleh para dosen dalam menginternalisasikan nilai-nilai moral religius berbeda-beda. Hal ini sejalan dengan pendapat Simon, Howe, dan Kirschenbaum (Wahab, 2007:1.23) yang menyatakan bahwa dalam menginternalisasikan nilai-nilai moral dapat menggunakan em- 
pat pendekatan yang meliputi pendekatan penanaman moral, pendekatan transmisi nilai bebas, pendekatan teladan, pendekatan klarifikasi nilai. Hasil penelitian ini menggambarkan bahwa pendekatan yang digunakan dalam menginternalisasikan nilai-nilai moral religius yang diterapkan oleh para dosen di Jurusan Pendidikan Kewarganegaraan dan Hukum meliputi: pendekatan penanaman moral, pendekatan teladan, dan pendekatan klarifikasi nilai.

Pendekatan penanaman moral digunakan untuk menanamkan nilai-nilai moral yang dianggap sudah seharusnya diterima karena keberadaannya tidak perlu diragukan lagi. Nilai-nilai moral religius seperti aqidah keagamaan dan ketaqwaan merupakan nilai moral yang keberadaannya tidak diragukan lagi. Pendekatan ini digunakan oleh dosen melalui penerapan strategi penguatan nilai-nilai moral religius yang telah dimiliki oleh mahasiswa. Penguatan terhadap nilai moral religius ketaqwaan yang dimiliki oleh mahasiswa salah satunya dapat dilakukan dalam pembelajaran Pendidikan Agama. Melalui materi pembelajaran Pendidikan Agama, dosen dapat melakukan penguatan-penguatan terhadap nilai ketaqwaan yang dimiliki oleh mahasiswa.

Pendekatan teladan digunakan untuk mengajarkan nilai-nilai moral melalui penunjukkan figur publik yang kepribadiannya patut diteladani.Figur publik ini misalnya para nabi atau rasul, dosen atau guru, orang tua, tokoh masyarakat, ilmuwan, dan ulama. Pendekatan ini digunakan oleh dosen melalui penerapan strategi keteladanan (modeling). Keteladanan yang digunakan da- lam penanaman nilai-nilai moral religius ini berupa keteladan internal dan eksternal. Secara internal, dosen sebagai figur yang dapat dijadikan teladan. Dosen memberikan teladan dalam berbagai hal yang baik; seperti mengawali dan mengakhiri perkuliahan dengan berdoa, berutur kata dan berperilaku yang sopan, memiliki tanggung jawab, jujur, disiplin dalam memberi kuliah, adil, dan ikhlas dalam mengerjakan segala sesuatu. Secara eksternal dapat dilakukan dengan memberikan contohcontoh yang baik dari para tokoh yang dapat diteladani.

Pendekatan klarifikasi nilai digunakan dalam pemantapan nilai-nilai moral melalui proses pengkajian, pemilihan, dan penerapan nilai yang dihadapinya. Pendekatan ini digunakan oleh dosen melalui penerapan strategi analisis masalah atau kasus dan penanaman nilai edukatif yang kontekstual. Melalui analisis kasus atau masalah kontekstual yang mengandung nilai-nilai edukatif mahasiswa dapat mendapatkan nilai positif dan negatif dari sebuah kasus. Setelah permasalahan selesai mahasiswa dapat mengambil hikmah atau nilai positif dan dapat belajar dari masalah yang dipecahkan tersebut. Selain itu, mahasiswa juga dapat menerapkan dalam kehidupan mereka terhadap nilai yang baik dari hasil analisis kasus yang telah diselesaikan dalam pembelajaran.

Di samping menggunakan pendekatan yang telah dikemukakan, internalisasi nilai-nilai moral religius dalam proses pembelajaran di perguruan tinggi seharusnya juga dilakukan secara komprehensif. Seperti dikemukakan Howard Kirschenbaum (1995:16-17), 
pendekatan komprehensif dalam pendidikan nilai dapat dijadikan sebagai pilihan. Isi pendidikan nilai yang akan ditanamkan kepada mahasiswa harus komprehensif. Dalam konteks internalisasi nilai-nilai moral religius dalam proses pembelajaran, maka nilai-nilai moral religius yang perlu menjadi prioritas utama meliputi nilai ketaqwaan, kejujuran, keikhlasan, dan tanggungjawab. Pemilihan nilai-nilai moral yang menjadi prioritas utama ini sejalan dengan fungsi dan tujuan pendidikan nasional, yaitu mengembangkan potensi peserta didik agar menjadi manusia yang beriman dan bertaqwa kepada Tuhan Yang Maha Esa, berakhlak mulia, sehat, berilmu, cakap, kreatif, mandiri, dan menjadi warga negara yang demokratis serta bertanggungjawab.

Nilai-nilai moral religius yang lain dapat ditanamkan di luar proses pembelajaran. Misalnya, melalui penciptaan sistem atau suasana kampus yang memungkinkan nilai-nilai moral religius dapat tertanamkan kepada mahasiswa dengan baik. Melalui slogan-slogan yang ada di setiap sudut kampus dapat dijadikan sebagai sarana untuk menanamkan nilai moral religius. Penciptaan program atau kegiatan kampus yang bernuansa religius dapat juga dikembangkan sebagai sarana yang dapat digunakan untuk menginternalisasikan nilai-nilai moral religius dalam kehidupan kampus. Penanaman nilai moral religius hendaknya tidak dilakukan secara parsial tetapi harus mencakup semua nilai-nilai moral religius.

Dari segi metode yang digunakan, internalisasi nilai-nilai moralreligius dalam pembelajaran juga harus dilakukan secara komprehensif. Para dosen harus dapat menjadi teladan bagi para mahasiswanya dalam bertindak dan bertutur kata. Mahasiswa perlu disiapkan agar menjadi generasi muda yang mandiri dengan mengajarkan dan memfasilitasi mereka dalam pembuatan keputusan moral secara bertanggungjawab. Selain itu, perlu membekali para mahasiwa dengan keterampilan-keterampilan akademik dan sosial. Mahasiwa dibekali keterampilan berpikir kritis dan keterampilan mengatasi konflik.

Internalisasi nilai-nilai moral religius perlu dilakukan dalam keseluruhan proses pendidikan di kelas, dalam kegiatan ekstra dan intra kampus, dalam proses bimbingan dengan penasihat akademik, dan dalam semua aspek kehidupan. Mahasiwa dapat melakukan hal ini melalui kegiatan diskusi kelompok, penggunaan bahan-bahan bacaan dan topik-topik tulisan mengenai kebaikan, penggunaan strategi dan klarifikasi nilai dan dilema moral, tidak merokok, tidak berperilaku korup, dermawan, tidak berbohong, dan sebagainya. Internalisasi nilai-nilai moral religius dapat dilakukan oleh setiap dosen, baik terencana ataupun tidak terencana. Kemudian yang terakhir, internalisasi nilai-nilai moral religius dalam proses pembelajaran harus komprehensif dalam segi penilaian. Efektivitas dan kemajuan dari kegiatan ini harus diukur secara komprehensif dengan menggunakan evaluasi formatif dan sumatif yang dapat mengukur pengetahuan, sikap, dan keterampilan yang dimiliki oleh mahasiswa. 


\section{KESIMPULAN}

Dari penelitian yang telah dilakukan, dapat disimpulkan bahwa strategi implementasi nilai-nilai moral religius yang diterapkan dalam proses pembelajaran di Jurusan Pendidikan Kewarganegaraan dan Hukum, Fakultas Ilmu Sosial dan Ekonomi, Universitas Negeri Yogyakarta meliputi: keteladanan (modelling), analisis masalah atau kasus, penanaman nilai edukatif yang kontekstual, penguatan nilai moral yang sudah ada. Nilai-nilai moral religius yang menjadi prioritas utama untuk dikembangkan dalam proses pembelajaran meliputi nilai moral ketaqwaan, kejujuran, keikhlasan, dan tanggungjawab. Masing-masing strategi yang digunakan dalam penanaman nilai moral religius tersebut memiliki kekurangan dan kelebihan masing-masing. Internalisasi nilai-nilai moral religius dalam proses pembelajaran di perguruan tinggi dapat menerapkan pendekatan komprehensif yang meliputi aspek isi, metode, waktu, pelaku, dan penilaian.

\section{UCAPAN TERIMA KASIH}

- Lembaga Penelitian (Lemlit) Universitas Negeri Yogyakarta yang telah mendanai penelitian ini melalui dana DIPA dengan surat perjanjian pelaksanaan pekerjaan penelitian nomor 02/H.34.21/MMPL/2008 tanggal $13 \mathrm{Ju}-$ ni 2008.

- Dekan Fakultas Ilmu Sosial dan Ekonomi, Universitas Negeri Yogyakarta yang telah memberikan kesempatan dan ijin untuk melaksanakan penelitian.

- Ketua Jurusan Pendidikan Kewarganegaraan dan Hukum, Fakultas Ilmu
Sosial dan Ekonomi, Universitas Negeri Yogyakarta yang telah memberikan izin untuk melaksanakan penelitian.

- Bapak $1 b u$ dosen pengampu mata kuliah di Jurusan Pendidikan Kewarganegaraan dan Hukum, Fakultas Ilmu Sosial dan Ekonomi, Universitas Negeri Yogyakarta.

- Para Mahasiswa Jurusan Pendidikan Kewarganegaraan dan Hukum, Fakultas Ilmu Sosial dan Ekonomi, Universitas Negeri Yogyakarta.

\section{DAFTAR PUSTAKA}

Agustian, Ary G. 2008. Peran ESQ dalam Peningkatan Kualitas Pendidikan. Pidato Dies Natalis ke-44 Universitas Negeri Yogyakarta, 21 Mei 2008. Yogyakarta: UNY Press.

Arikunto, Suharsimi. 2006. Prosedur Penelitian: suatu Pendekatan Praktek. Jakarta: Rineka Cipta.

Bertens, K. 2007. Etika. Jakarta: Gramedia Pustaka Utama.

Cholisin. 1989. Dasar dan Konsep Pendidikan Pancasila. Yogyakarta: Laboratorium Jurusan PMP dan KN.

Kirschenbaum, Howard. 1995. 100 Ways to Enhance Values and Morality in Schools and Youth Settings. Massachusetts: Allyn \& Bacon.

Koyan, I Wayan. 2000. Pendidikan Moral Lintas Budaya. Jakarta: Dirjen Dikti, Depdiknas. 
Nazir, Moh. 2005. Metode Penelitian. Bogor: Ghalia Indonesia.

Republik Indonesia. 2005. Undang-Undang Nomor 20 Tahun 2003 tentang Sistem Pendidikan Nasional. Bandung: Fokusmedia.

Ruminiati.2007.Modul Pendidikan Kewarganegaraan SD: Untuk Program S1
PJJ. Jakarta: Dirjen Dikti, Depdiknas R.I.

Wahab, Aziz. 2007. Pendidikan Pancasila danKewarganegaraan (PPKn). Jakarta: Penerbit Universitas Terbuka.

Zuchdi, Darmiyati.2008.Humanisasi Pendidikan: Menemukan Kembali Pendidikan yang Manusiawi. Jakarta: Bumi Aksara. 